JNUS:Journal of Nahdlatul Ulama Studies Vol. 1, No. 1, Januari 2020: h. 34-66. DOI: 10.35672/jnus.v1i1.34-66

Website: http://jnus.lakpesdamsalatiga.or.id/index.php/jnus/index

\title{
Cultivating Islam Nusantara in Indonesia's Pesantrens: a Promising Deradicalisation Strategy?
}

\author{
Irfan L. Sarhindi \\ University College London \\ sarbindi@gmail.com
}

\begin{abstract}
The purpose of this study is to demonstrate to what extent the cultivation of discourse of Islam Nusantara in Indonesia's pesantren. This is a qualitative research. The method of collecting data is through documentation. The research finding showed that Pesantrens had proven themselves to be the fortress of cultural Islam. They have maintained the moderate face of Indonesian Islam. Their flexibility has shown as useful when Islamic education is the concern. However, the use of media as the source of Islamic knowledge has a certain degree that becomes the vehicle by which radical Muslims spread propaganda and hoaxes.
\end{abstract}

Keywords: Islam Nusantara, Pesantren, Deradicalitation Strategy

\section{INTRODUCTION}

This study aims to demonstrate to what extent the cultivation of the discourse of Islam Nusantara in Indonesia's pesantrens (Islamic traditional boarding schools) can hinder the growing of Islamic radicalisation. In a nutshell, Indonesia has witnessed the rise and the spread of radical Islam (Sakai \& Fauzia, 2014). Besides nurturing its members through various organizations (Fox, 2004; Tan, 2011), the spread of radical Islam undertakes the optimization of media, either offline and online (Dearden, 2017; Mujiburrahman, 2007; Muzakki, 2014; Noor, 2013; Springer, Regens, \& Edger, 2009; Varisco, 2010). Included in this optimization is the dissemination of hoaxes. Surely, the =turn back hoax' movement (see Dahono, 2016) is insufficient if long-term objectives are the concern. One out of many alternatives I propose here is the cultivation of Islam Nusantara in Islamic education, specifically in pesantrens. Beside capable of encouraging the contextualization of Islamic thinking, the cultivation of 
Islam Nusantara in pesantrens could strengthen the instrumental role of pesantrens as the fortress of Indonesian =Islam with the smiling face' (see Abdul \& Zakaria, 2010; Azra, 1999; Bizawie, 2016b; Lukens-Bull, 2013; Musa, 2014; Tim Penulis JNM, 2015).

The discussion will be begun by the articulation of the interplay between media and the growing of Islamic radicalisation. It will be followed by the discussion about the campaign of Islam Nusantara in relation to Nahdlatul Ulama (The Awakening of Islamic Scholars-NU) and the re-identification of Indonesian cultural Islam. Afterwards, I will investigate the role of pesantrens in the context of Indonesian Islam. Aligned with this is the examination of whether or not pesantrens are still the fortresses of Indonesian Islam. Resumed from this is the contestation about how the cultivation of Islam Nusantara in pesantrens could deradicalize Indonesian Muslims. Finally, I will draw some conclusions.

\section{DISCUSSION}

\section{Religiosity and Media: The Rise of Radical Islam?}

Briefly, religiosity is a religious commitment (Hassan, 2007). It appears that religiosity has been, and will always be, the instrumental role of Indonesian people's lives (see A'la, 2014). The reasons are as follow. First, Indonesian people are obliged to submit to one religion. Although Indonesia only recognizes six official religions, this does not necessarily mean that Indonesian people cannot subscribe to religion outside the six. Alongside these six official religions, Indonesia also acknowledges around 245 kepercayaan (beliefs) (see Tarsono, 2015). Even though religion is sometimes understood as a private concern, Indonesian people are encouraged, if not required, to declare their religions in their citizen cards (Direktorat Jenderal Kependudukan dan Pencatatan Sipil, 2013). Second, the first principles of Pancasila, Indonesia's ideology, explicitly emphasizes the recognition, if not obligation, to belief in God. Third, the idea that Indonesia's independence was not solely achieved by people's struggle, but most importantly, by the help of God (The Constitutional Court of the Republic of Indonesia, 2015). Fourth, the insistence of religiosity can 
JNUS: Journal of Nahdlatul Ulama Studies, Vol. 1, No. 1, Januari 2020: 34-66

also be traced in the slogan of Bhinneka Tunggal Ika (unity in diversity). Before this notion is widely used to embrace the diverse society of Indonesia, this notion was addressed by Mpu Tantular to reconcile the members of Hindu and Buddha (Memory of Majapahit, 2007). It can be argued that rather than perceived as a secular country (see al-Amin, 2012; Azra, 2004; Ba'asyir, 2006), Indonesia is better understood as a religious country (Mas'udi, 2016; Ramage, 1995; Saeed, 1999; Syamsudin, 2016).

When comes to Islam, religiosity is even more emphasized. Firstly, Islam requires Muslims to implement Islamic norms and principles wholeheartedly ${ }^{1}$ (kaffah) (Quran, n.d.). Secondly, Islam itself rules the life of Muslims in every aspect. ${ }^{2}$ Thirdly, the insistence of akhlak karimah (noble attitude or virtue), as a product or expression of religiosity, with the prophet as the perfect example, can be found in Hadith ${ }^{3}$ (Sunnah, n.d.). This is also cultivated in Islamic educational institutions; legitimized by the authority. For instance, the aims of education, mentioned in the latest National Curriculum, is to produce a student who is religious and nationalist (Departemen Agama, 2003; see also Kurniasih \& Sani, 2014; Parker, 2016). Drawing on this findings, it is not surprising to find how atheism is perceived as such disease (Osman, 2012). Consequently, atheist people are viewed as less kind, as well as Muslims who are not fully practicing Islam, known as Muslim abangan'.

Indonesian Muslims are commonly religious (Hassan, 2007). For Azra (1999), the increasing trend of religiosity was provoked by the wave of santrinization when pesantrens moved from villages to cities. This was accelerated by the modernization of Islamic education when Sekolah Islam was founded (see Zuhdi, 2006). Notwithstanding this, the increasing interest in religiosity is also influenced by the accelerative growth of technology which has provided Muslims a various media, either offline or

${ }^{1}$ QS 2: 208

${ }^{2}$ It can be seen by how figh (Islamic law and jurisprudence) is composed of numerous rules concerning ubudiyah (worship), muamalah (socio-economics affairs), munakah (marriage), and siyasah (politic and war). manners."

3 Narrated by Bukhari, the Prophet said, "I was sent but to perfect good 
online, to learn Islam (Azra, 2005; Sakai \& Fauzia, 2014). Almost all TV stations have their Islamic teaching shows. Numerous Islamic books are published. This is not to underrate the role of Islamic magazine and pamphlets. When gadgets are sold intensively, and the internet is far more reachable, the internet becomes another important source of learning Islam. What is more is when social media is widely used.

Until recently, $85 \%$ of 259.1 million Indonesian citizens have a cell phone in which 43\% of them are smartphones (Balea, 2016). Internet users are perceived to number 100 million users (eMarketer, 2016b). Mobile web traffic has reached 79\% (Balea, 2016; Loras, 2016) with Facebook names to be the most popular social media website (eMarketer, 2016a). Since 70\% of Facebook users also use Instagram (eMarketer, 2016a), it can be argued that internet users in Indonesia typically use more than one social media. Follows from this is three conditions. Firstly, some Islamic organizations and Islamic schools force themselves to expand their public services by having social media accounts (Hendroyono, 2004; Ritchey \& Muchtar, 2000). Even some kiais and their teachings can now be found in their social media accounts. Secondly, the internet and particularly social media have made it easier for people to post or to spread anything regardless of the reliability of the content and the impact it will provoke (Abbott, 2011; Gregerson, 2012; Hamayotsu, 2013; Lim, 2013a; Loras, 2016; Varisco, 2010). When comes to the learning of Islam on the internet, a lack of guidance and less reliable content are threatening to mislead Muslims in understanding Islam (see Lim, 2013b). It is perhaps exacerbated by the third condition which is the assumption that radical Muslims are more capable of optimizing media in comparison to the moderate ones (BBC Worldwide Limited, 2016; Lim, 2005).

In a nutshell, radical Muslims can be indicated by three characteristics. First is that they hold a literal understanding of Islamic scriptural sources and historical narratives (Azra, 2005; Gillespie, 2007; Rahman, 1980; Sonn, 1991; van Bruinessen, 2013). Second is that they promote the establishment of a caliphate and Islamic Sharia (al-Amin, 2012; Ba'asyir, 2006; Ngelow, n.d.; M. N. M. Osman, 2010; Tan, 2011). 
JNUS: Journal of Nahdlatul Ulama Studies, Vol. 1, No. 1, Januari 2020: 34-66

Third is that they are doubtless in performing violence in the name of jihad (Al-Qurthuby, 2015; Jati, 2013; Springer et al., 2009). Islamic organizations which are described as having radical expression of Islam are the likes of Islamic Defender Front (Front Pembela Islam-FPI), Hizbut Tahrir Indonesia (Liberation Party of Indonesia-HTI), and Jamaah Islamiyah (Islamic Congregation-JI) (al-Amin, 2012; Ba'asyir, 2006; Temby, 2010; Wildan, 2013; Woodward et al., 2014). However, my research on the nature of these three indicates that neither of them has all characteristic. In most cases, they only hold two out of three features described. For instance, HTI is confident in campaigning its conception of the caliphate, but it insists the need to avoid violence (al-Amin, 2012). Besides organizing various organizations, media is arguably the instrumental role of their campaigns (Azra, 2004; Fox, 2004; Mujiburrahman, 2007; Muzakki, 2014; Springer et al., 2009). Before it turns to the optimization of the internet and social media, Islamic radicalisation was evident in the spreading of free Islamic pamphlets (Fox, 2004; Lukens-Bull, 2013; Muzakki, 2014; Osman, 2010). The huge role of media in spreading propaganda is acknowledged by ISIS which states that the propaganda spread out by the media is more impactful than suicide bombings (Dearden, 2017).

If it is the case that radical Muslims are more capable of optimizing media to spread propaganda, then in the Indonesian context, they are far more threatening to Islamic radicalisation for following reasons. First is it seems that they are doubtless in spreading hoaxes as long as their goals are about to be achieved (Amelia, 2016; Berita Satu, 2017; Fathoni, 2016; Zulfa \& Alhafiz, 2016). Hence, hoaxes could endanger social cohesion. Second is the active participation in social media and the use of the internet as the utmost source of Islamic teachings are seemingly not equipped with a sufficient basic understanding of Islam (see Fealy, 2004). This is exacerbated by the fact that Indonesian Muslims are less critical (Madjid, 2003) and that Indonesia is the second latest less literate country (Gunawan, 2016; Miller \& McKenna, 2016). Consequently, Indonesian Muslims are vulnerable to be manipulated and 
radicalized. The horizontal conflict which interplays with the Jakarta's governor election can be used as an example (Fealy, 2016; Ropi, 2016). This was also partly influenced, I suspect, by the similarity between radical Muslims with the moderate conservative Muslims in the sense that they share a literal approach in interpreting Islam (van Bruinessen, 2013). With such a situation, Sakai and Fauzia (2014) argue that the percentage of radical Muslims has increased up to $20 \%$. To counteract the trend, NU initiates a campaign known as Islam Nusantara.

\section{Nahdlatul Ulama and Islam Nusantara}

Claiming for more than 88 million members ${ }^{4}, \mathrm{NU}$ is the biggest Islamic organization in Indonesia and presumably in the world (see Manshur, 2014; Van Bruinessen, 2013). Nowadays, NU has nearly 40.000 branches, 18 institutes, and numerous autonomous sub-organizations (see Anom \& Fathoni, 2016; NU Online, 2015). NU holds a traditional Sunni Islam. It is proud to be characterized as tawassuth (moderate), tawazzun (fair and balanced), and tasammuh (tolerant)(Bizawie, 2016b; Tim Penulis JNM, 2015). Grounded upon the huge network of Muslim intellectuals (kiais) and their santris (students), NU was founded by Hasyim Asyari the hadratus syaikh (grand teacher). Its embryo was evident in the establishment of Taswirul Afkar (the Portrait of Thought) back in 1914. Before it came to the final form of Nahdlatul Ulama, it has undergone two transformations (Siroj, 2016). Despite the fact that NU was partly structured as the response of the establishment of Muhammadiyah and the coming of Wahhabism to Indonesia, the aims of this organization are to establish a democratic society which constitutes justice, the protection of human rights, the encouragement of flourishing life, and prosperity (Fatoni, 2016).

\footnotetext{
${ }^{4}$ The exact number of NU's members is hard to be traced (see Manshur, 2014). This estimation is based on my own analysis. In Balea (2016), Indonesian population reaches 259.1 million people. Around $81 \%$ of them are Muslims (Manshur, 2014; Raihani, 2014). Therefore, Indonesian Muslims are approximately 209.9 million people. In Van Bruinessen (2013), NU possesses $42 \%$ of Indonesian Muslim population, therefore, NU's members are about 88.15 million people.
} 
JNUS: Journal of Nahdlatul Ulama Studies, Vol. 1, No. 1, Januari 2020: 34-66

Since its early establishment, NU has proven itself as supportive to Indonesia's ideology and therefore Indonesia's governmental system (Mas'udi, 2016; Wahid, 2006, 2016a). According to Abdurrahman Wahid (Gus Dur), the hadratus syaikh was determinant in succeeding Pancasila as Indonesia's ideology (Wahid, 2016b). This alone indicates NU's philosophical standpoint vis-à-vis radical Islam. For radical Islam, Pancasila disrupts the core value of Islam. Hence Indonesia's governmental system is viewed as infidel system (Ba'asyir, 2006). Enacting caliphate, furthermore, is believed to be a liberation struggle (al-Amin, 2012; Osman, 2010). For NU, Pancasila walks hand in hand with Islamic values and principles. Indonesia's governmental system, moreover, is believed to be based on consensus yet consensus is accommodated in Islam (see Syamsudin, 2016). With this in mind, Bhinneka Tunggal Ika (unity in diversity) appears to be in accordance with the spirit of Medina Charter in the time of the Prophet. Even though NU is acknowledged as expressing traditional Islam, and that some of its members are conservatives, the accommodation to Indonesian culture and the acceptance of Indonesia's ideology and governmental system seem to prove that the contextualization of Islamic thinking did, and does still, occur. With this philosophical standpoints, NU has helped Indonesian Muslims develop a dialogue between Islam and democracy; Islam and nationalism (see Musa, 2014).

The identity of NU, needless to say, cannot be separated from the historical narrative of Wali Songo (nine saints) and Jawi (Javanese) community in Mecca in 16th and 17th century, respectively (Azra, 1992; Bizawie, 2016b; Muhammad, 2012; Tim Penulis JNM, 2015). Therefore, when NU released the campaign of Islam Nusantara in its 33rd muktamar (conference) in 2015, it recalls the historical narratives of Wali Songo and Jawi Community as to justify the campaign as the new package of the old conception'. However, Islam Nusantara is sometimes suspected as merely a chauvinistic expression of Islam (Affan, 2016; Fachrudin, 2016). Despite capable of disrupting the universality of Islamic values and principles, this campaign was also perceived as the conspiracy of secular and liberal 
Muslims to destroy the very principle of Islamic orthodoxy (Fatoni, 2016; Penebar Cahaya Islam, 2016). For Fachrudin (2016), these polemics come up as the result of the use of the notion of Nusantara'. NU remains unclear, Fachrudin argues, with its intention to use the word either as a cultural entity or merely geographical location. Other than that, this is also problematic for it forces NU to embrace all kinds of Islam that grow in Indonesia included the radical ones. That is if it can be accepted that irrespective of the fact that the mainstream Indonesian Muslims are moderate, the minor radical Muslims are also home-grown (see Fealy, 2004).

Nonetheless, Islam Nusantara presents a clear opposition toward radical Islam. This can be indicated by how the idea of Islam Nusantara contradict Wahhabism version of the pure Islam (Affan, 2016; see Azra, 2016; Bizawie, 2016a). IslamNusantara is perceived as the series of a footnote of Gus Dur's idea of Pribumisasi Islam' (the Indigenisation of Islam) (Bizawie, 2016a, 2016b; Fatoni, 2016; Ghazali, 2016; Muhadjir, 2016; Staquf, 2016; Tim Penulis JNM, 2015). Islam Nusantara is often defined as Islam in, and from, Nusantara (Bisri, 2016). The use of the word Nusantara' seems to emphasize the early preaching of Islam to Indonesia in the hand of Wali Songo when the name of Indonesia' was not yet found. This is not to avoid the claim that the territory of Nusantara in the time of Majapahit Kingdom reach as far as Indonesia and Malay Peninsula (Tim Penulis JNM, 2015); and even to somewhere in Pacific and Madagascar (Evers, 2016). As Islam which is in, and from, Nusantara, the campaign of Islam Nusantara displays the accommodation of the dialogue between Islamic thinking and Nusantara's culture. Therefore, Islam was interpreted not as a static value with the Arab origin but as something that can walk hand in hand with the culture in which Islam was spread and taught (Alawi, 2015; Bagir, 2016; Ghazali, 2016; Staquf, 2016; Wahid, 2016b). Accordingly, Islam Nusantara is composed of three principles. First is the contextualization of Islamic thinking. Second is the acculturation between Islam and local culture. Third is the support to Indonesia as a state and its ideology. Therefore, 
JNUS: Journal of Nahdlatul Ulama Studies, Vol. 1, No. 1, Januari 2020: 34-66

philosophically, the campaign of Islam Nusantara can be adopted in other places in the interest of the cultivation of cultural Islam (see Muhadjir, 2016).

Drawing on this line, Islam Nusantara champions the moderate Islam which is also known as cultural Islam; represented by $\mathrm{NU}$ and Muhammadiyah (van Bruinessen, 2013). Radical Islam, on the other hand, is perceived as political Islam for it believes that Islam needs to be manifested in political realm through the enactment of the caliphate (alAmin, 2012; Ba'asyir, 2006; Osman, 2010; Tan, 2011). Besides accommodative to the acculturation between Islamic thinking and culture, cultural Muslims believe that Islam does not have to be a political system. Islamic values and principles should, first and foremost, be embodied in the heart of Muslims, manifested in their socio-cultural lives. However, in a matter of content, Islam Nusantara was suspected as merely representing NU's type of Islam (Fachrudin, 2016). This suspicion comes up as the result of how Islam Nusantara is sometimes characterized by the core characteristics of NU which are tawassuth (moderate), tawazzun (fair and balanced), and tasammuh (tolerant). Although the like of Muhammadiyah holds similar gestures of Islam (see PP-Muhammadiyah, 2000), the use of this exact notions implicates strong impression that Islam Nusantara is only NU's agenda. This appears to hinder the contribution of moderate Indonesian Muslims who see themselves as not affiliated to NU. Two approaches can be taken in this regard. First is the re-definition of Islam Nusantara so as to embrace the like of Muhammadiyah. This can be undergone by, at least, acknowledging the wave of Islamic reformism as part of the diverse identities of Indonesian Muslims. This will create several problems, I suspect, but this is beyond the discussion. My main focus here is to the second approach, that is, the strengthening of cultural Muslims in the fortress of cultural Islam: pesantrens.

\section{Pesantrens: the Fortresses of Cultural Islam?}


Indonesia's Islamic education can be of four kinds ${ }^{5}$ : pesantrens (traditional Islamic boarding schools), madrasah, Sekolah Islam, and Islamic Higher Education. Amidst these four, pesantrens are arguably the oldest and the most instrumental (Abdul \& Zakaria, 2010; Tan, 2011). Historically, pesantrens were commonly located in a restricted area (Azra, 1999; Azra \& Afrianty, 2005; Rosidin, 2012). They have been responsible for empowering the poor and the subaltern people (see USAID, 2007). Pesantrens adopt the conception of Hindu's padepokan which is similar to Christian's monastery excluding the commitment of celibacy (Geertz, 1960; Madjid, 2003; Pringle, 2016). The basic compositions of pesantrens are kiais, santris, kitab kuning (yellow book), dormitory, and mosque. Basic facilities that can be found in pesantrens are shared kitchen and bathroom, kiai's house, and classrooms (see Pringle, 2016). In pesantrens, learning is held $24 / 7$ with self-transformation as the aim. In so doing, experiential learning is emphasized. That is to say that the success of learning is not measured by how expertise the santris are, but how knsowledge they get is implemented in their daily lives (Musa, 2014). Pesantrens, therefore, embrace all the verdicts of the philosophy of Islamic education which are ta'dib (nurturing ethics and manner), tarbiyah (upbringing or bildung), and ta'lim (transferring knowledge) (Halstead, 2004; Nor \& Malim, 2014; Waghid, 2014). With this philosophical standpoint, pesantrens commonly do not grant any graduation certificates. The establishment of pesantrens cannot be separated from the maintenance of Sufi brotherhood (Dhofier, 1980; Rosidin, 2012). This is because the first kind of Islam which came to Indonesia is Sufisminfluenced Islam (Azra, 1992; Bizawie, 2016b; Hefner, 2012; Howell, 2001). This can be indicated, firstly, by the use of al- Ghazali's works (van Bruinessen, 1990; Van Bruinessen, 1994). Al-Ghazali, moreover, was

5 In Tan (2011, 2014), Islamic education is divided into three categories: pesantrens, madrasahs, and Sekolah Islam. However, given the instrumentality of Islamic Higher Education, I therefore decide to add this as the fourth category of Islamic education. The huge role of Islamic Higher Education for Indonesian Muslim society can be traced in Azra (2008, 2015), Jackson and Bahrissalim (2007), Kraince (2007), Kull, Lukens-Bull (2001), and Nasuhi and Darmanji (2009). 
JNUS: Journal of Nahdlatul Ulama Studies, Vol. 1, No. 1, Januari 2020: 34-66

known as the founder of Sharia-based Sufism, that is, Sufism which is based on Islamic law and jurisprudence (Ansary, 2009). Secondly, the notion of Wali' in Wali Songo'. The idea that a Muslim, through devotional Sufi practices, can lift her religious status to be a saint, can only be found in Sufi. In this regard, al-Ghazali classifies human beings into seven classes. The highest two are the prophet and the saint (Al-Ghazali \& Faris, 1966; Raindrop Academy, 2015b). Thirdly, Sufism has softened Islamic thinking to a degree it could cope with local cultures. Indeed, the acceptance of Islam by Nusantara's people is perceived to be partly provoked by the similarity between Sufism with Indonesia's pantheism, founded in the idea of wahdatul wujud or manunggaling kawula Gusti, that is the idea that God is the only Dzat (entity) that is real (Madjid, 2003). The cultivation of Sufism, therefore, strengthens the embodiment of cultural Islam.

Radical Islamic organizations and movements perceive Sufism as destructing the core principles of Islam (Smith \& Hamdi, 2013). Such suspicion is perhaps driven by the fact that Sufism constitutes the contextualization of Islamic thinking. For Muslims who hold the literal understanding of Islam, Sufism implies bid'ah for some of its devotional practices cannot be found in the life of the prophet. However, I might argue that Sufism can be named as Islamic de-radicalisation campaign for following reasons. Firstly, Sufism defines jihad as self- and soul transformation (Ramadan, 2008). Unlike the radical expression of Islam which is doubtless in provoking violence in the name of God, Sufism concerns in introspection and retrospection in the interest of wisdom (see Al-Ghazali \& Faris, 1966; Ocean of Wisdom, 2015; Raindrop Academy, 2014, 2015a, 2015b, 2015c, 2016). Since self-transformation could nevertheless provoke the socio-cultural transformation, the long-term effect of Sufism is the maslahah al-ummah (goodness of society) which constitutes justice, equality, protection, and pluralism (Muhammad, 2016; Sahal, 2016; Wahid et al., 2016; Zaqzuq, 2004). This can be strengthened by how Sufism emphasizes sincerity, simple living, and self-sufficiency (Lukens-Bull, 2013). Secondly, the cultivation of Sufism in pesantrens has 
brought about various traditions such as Takbir Keliling' (walking around by reciting Allahu Akbar ${ }^{6}$ or God is Great'). Woodward, Amin, Rohmaniyah, and Coleman (2010) argue that such tradition cannot be found in the likes of Wahhabism and that this could strengthen social cohesion.

In Foucauldian perspective, the role of pesantrens in the embodiment of Islamic virtue in the heart of santris can be deconstructed in the metaphor of panopticon. The very idea of panopticon, as its function in the architecture of prison, is the idea of being monitored and the sense of surveillance. This kind of feeling could enforce prisoners to behave what is called as normal, such as of obeying the prison's rules (see Ball, 2013; Gore, 1998). In Islam, the idea that the Muslims are monitored in all aspect of their lives can be found in the conception of rukun ihsan (the principle of kindness). In rukun ihsan, a Muslim should behave just like she can see the God; even if she cannot feel that she can see the God, she ought to believe that God is all-knowing and nothing is absent from His knowledge. This is to say that in pesantrens, such a disciplinary power is exercised to the degree that it - reaches into the very grain of individuals, touches their bodies and inserts itself into their action and attitudes, their discourses, learning processes and everyday lives (Foucault 1980: 39). Rukun ihsan is perceived as the highest level of faith (Madjid, 2003).

The metaphor of panopticon can also be indicated in the huge influence of kiais to santris. In this regard, kiais act as the guards. However, unlike the role of a guard in Foucault's metaphor, the influence of kiais as constituting the disciplinary power to the lives of santris, is also driven by the will of santris to exemplify their kiais. In Indonesian Muslim society, kiais gain a huge power to the degree that they have a Weberian charisma (Bizawie, 2016b; Geertz, 1960; Pringle, 2016; Van Bruinessen, 1994). Spencer (1973) argues that Weberian charisma is built upon the idea that an individual has a supernatural power. This idea then, according to Smith (2013), is validated by her followers. In Marshall (2012), such charisma constitutes personal qualities which make the followers perform 
JNUS: Journal of Nahdlatul Ulama Studies, Vol. 1, No. 1, Januari 2020: 34-66

a total obedience. The Weberian charisma of kiais appears to be legitimized by scriptural sources of Islam where knowledge and ulama (intellectual) are praised (Musa, 2014); validated by the prophet who states that ulama is his heirs (Sunnah, n.d.). This is strengthened by Sufism tradition who underlines the total respect and obedience to the murshid (teacher and leader of Sufi brotherhood) (Muizzuddin, 2012; Rosidin, 2012; Tim Karya Ilmiah Purna Siswa, 2014).

In pesantrens, such tradition is maintained by the instalment of the core ethics of learning, founded in the learning of Zarnuji‘s book, ta'lim muta'alim (2004), and al- Ghazali‘s book, Ihya Ulum ad-Diin (1966). This is supported by the characteristic of pesantrens' learning methods which are teacher-centred: sorogan and bendogan (Bizawie, 2016b; Musa, 2014; Van Bruinessen, 1994). In sorogan, santris are expected to memorize the definition and the grammatical function of each word in kitab kuning, dictated by kiais. In bendogan, kiais still dictate the definition and the grammatical function of each word in kitab kuning but santris are expected only to write it down. Both methods emphasize the rote of memorization. Commonly, there is no allowance for discussion (Van Bruinessen, 1994). Consequently, pesantrens are appeared to hinder critical thinking which results in the less-critical santris. If this is the case, then the moderate expression of santris is built upon their obedience to their moderate kiais rather than upon their deep understanding of Islam. As a consequence, they will still be easily manipulated (see Milla, Faturochman, \& Ancok, 2013; Sirozi, 2005; Tan, 2011). Of course, it is difficult to deny how the total obedience to the moderate kiais has been responsible for the maintenance of cultural Islam in Indonesia. Nonetheless, given the huge role of media in spreading propaganda and hoaxes, total obedience can be fairly insufficient.

\section{Islam Nusantara, Pesantrens, and Islamic De-Radicalisation Campaign}

The optimization of the campaign of Islam Nusantara as to de-radicalize Indonesian Muslims can be undergone by enriching the discourse of 
moderate and cultural Islam in the internet and social media, as has been done by NU Media Troops (see Fathoni, 2016; Najmudin \& Alawi, 2016; Zulfa \& Alhafiz, 2016). However, to a certain degree, as I will show you later in this section, it appears to be insufficient. It seems that such optimization needs to be boosted by the cultivation of this discourse in pesantrens. First, NU has a huge influence on the nature and the maintenance of pesantrens. Even the former campaign, which can be argued as still aligns with Islam Nusantara, is called Kembali ke Pesantren“ (Back to Pesantrens) (Fatoni, 2016). In so doing, NU tries to re-brand pesantrens which sometimes are viewed as less affordable for they do not equip santris to cope with the workforce requirement. The cultivation of Islam Nusantara in pesantrens, therefore, is not only relevant for the sake of NU's standpoint and program but also instrumental in the interest of the embodiment of deep understanding of cultural Islam in the heart of santris. Second, both Islam Nusantara and pesantrens are the legacy of Wali Songo and Jawi Community (see Bizawie, 2016b; Tim Penulis JNM, 2015; Wahid et al., 2016). Pesantrens were the first educational environment where $=$ Islam in, and from, Nusantara' was cultivated and developed. When an attempt to conceptualize this Islam in, and from, Nusantara' was shown, disseminating it in the place where this was at first born will be beneficial. Not only will this strengthens the philosophical insight of the discourse, but also will this strengthen the essential role of pesantens as to promote democracy, civil society, pluralism, gender equality, and human rights. I have argued that Islam Nusantara constitutes the accommodation of the acculturation between Islam and Indonesian culture, the acceptance and support to Indonesia's ideology and governmental system, and the contextualization of Islamic thinking. I have also indicated how those three are evident in pesantrens. To mention another example is to address =Aksara Arab Pegon' (Bizawie, 2016b). This is the combination between Arabic lettering with the Javanese language. This was perceived as the symbol of the struggle against the Dutch. However, the implementation and the development of those three appear to be less 
JNUS: Journal of Nahdlatul Ulama Studies, Vol. 1, No. 1, Januari 2020: 34-66

equipped by such a deep understanding of cultural Islam. This is to say, a total obedience to kiais could lead to a blind imitation (taqlid). For alGhazali, blind imitation is the weakest level of faith (Raindrop Academy, 2015b). Perhaps, this is because taqlid will hinder santris to drill, and therefore understand, the essence of Islamic values. As a result, Islam is merely expressed formally and symbolically. What follows from this is a suspicion that the contextualization of Islamic thinking would endanger the core value of Islam.

Drawing on this line, I argue that the cultivation of Islam Nusantara in pesantrens should be equipped by the dissemination of critical thinking. According to Bailin and Siegel (2008, p. 181), thinking can be classified as critical if, and only if, -it meets relevant standards or criteria of acceptabilityll. Justification is the word that is expressed by Kurfiss (1988) in this regard. For Bailin and Siegel, critical thinking is composed by skill and disposition; it has general applicability as well as is sensitive to context. While skill is what makes thinking meets certain relevant criteria, the disposition is what forces it to do so. Disposition, they continue, is built upon open-mindedness, fair-mindedness, independent-mindedness, curiosity and respect for other viewpoints. It is supported by Kincheloe (2008) and Moon (2007), who state that critical thinking is composed by the act of reasoning, meaning-making and contextualizing. Questioning is the characteristic of critical thinking given by Hytten (2004) while Weil (2004) believes it is an examination. It links, I suspect, to Dewey's idea of reflective thinking (1993). Accordingly, reflective thinking is the act of problematizing, identifying, hypothesizing, reasoning and experimenting. Its bottom line effort, perhaps, relies on thinking itself which is defined by Dewey as questioning.

I am fully aware that critical thinking is often viewed as capable of endangering the faith. However, for me, critical thinking, first and foremost, walks hand in hand with the spirit of =Iqra' (to recite!) as the first revealed verse of Quran. Even Quran itself repeatedly states the word 
yatafakkarun $^{6}$ which means - to thinkll (Quran, n.d.). Al-Ghazali insists that - nobody becomes knowledgeable just by quoting from authoritative texts-knowledge takes shape in an individual mind seeking truth (in Albertini, 2005, p. 3). Its compatibility becomes rather difficult to reject if Bailin and Siegel's (2008) claims of the importance of critical thinking to education are articulated. For them, critical thinking becomes fundamental for education in four respects. Three of them are concerns in respecting students as individuals, preparing students for adulthood, and fostering understanding. All of these walk hand in hand, respectively in the conception of ta'dib, tarbiyah, and ta'lim.

Given such characteristics and contextualization, critical thinking tends to be helpful in finding out dalil (justification) and wisdom. As it could be helpful in optimizing Sufi meditation, it could also be helpful in the process of ijtihad (see Abdullah, 2016) or ifta' (asking for fatwa ${ }^{7}$ ), evident in bahtsul masail8 (the discussion forum). Through reasoning, reflection, and questioning, helped by the open- mindedness, a mujtahid - the one who does ijtihad- or mufty-the one who give a fatwa-can see the problem more holistically (Sahal, 2016). It is important, I argue, given the contemporary situation is more challenging to the life of Muslim regarding her faith. With open-mindedness and critical thinking as the capital, the mujtahid then could recognize the sacred source on the one hand, and the context on the other; or, on the other word, the contextualization of Islamic thinking. On the other hand, open- mindedness could encourage santris to recognize and therefore respect other viewpoints (A'la, 2014; see Adichie, 2009; Zaqzuq, 2008). This will arguably eradicate the potential of self-righteous and judgmental attitudes, evident in radical Muslims. Moreover, this could make santris

${ }^{6}$ For example Quran (16:11); (16:44); (59:21); (7:184); (45:13); (30:21); (16:69); (13:3); (30:8); (39:42); and (10:24).

7 A statement of authorized kiais concerning particular problems mainly in the domain of Islamic law and jurisprudence. This has no power to tie up the Muslims as this is seen as merely choice rather than obligation.

$8 \mathrm{~A}$ forum to discuss recent phenomenon so as to decide the comprehensive fatwa. 
JNUS: Journal of Nahdlatul Ulama Studies, Vol. 1, No. 1, Januari 2020: 34-66

difficult to be manipulated and radicalized. This will, by and large, weaken the influence of propaganda and hoax in steering Indonesian Muslims, let alone endangering social cohesion. It will, in the end, strengthen the core aims of the establishment of NU itself.

\section{CONCLUSION}

Pesantrens had proven themselves to be the fortress of cultural Islam. They have maintained the moderate face of Indonesian Islam. Their flexibility has shown as useful when Islamic education is the concern. However, the use of media as the source of Islamic knowledge has to a certain degree become the vehicle by which radical Muslims spread propaganda and hoaxes. Their campaigns are threatening given the fact that Indonesian Muslims are commonly less critical. On the other hand, Islam Nusantara aims to counteract Islamic radicalisation. It provokes the accommodation of acculturation, the contextualization of Islamic thinking, the support to nationalism and the acceptance of Indonesia's ideology and governmental system. Before it was firmly conceptualized and released by NU, the idea of Islam Nusantara is perceived as was born and is still cultivated in pesantrens. The optimization of the campaign of Islam Nusantara, therefore, can be started by disseminating its principles in the pesantren milieu.

In this regard, critical thinking appears to be necessary. Besides capable of encouraging a deep understanding of cultural Islam, critical thinking arguably can walk hand in hand with the philosophy of Islamic education maintained in pesantrens. As for NU itself, such an approach can empower the organization thus accelerates the fulfilment of its goals. However, to a degree, critical thinking appears to contradict the traditional orthodoxy held by NU and pesantrens. Hence, some kiais have a less humble approach to santris' questions. Drawing on this assumption, critical thinking could be difficult to be implemented even appears to be suspected as liberal's agenda to disrupt the core value of Islam. If it can be accepted that critical thinking is beneficial in the interest of the strengthening of moderate Islam, some determinations of the authority 
appear to be required. In this regard, the likes of Ministry of Religious Affairs and principals of NU can play their instrumental roles.

\section{BIBLIOGRAPHY}

A'la, A. (2014). Jahiliyah Kontemporer dan Hegemoni Nalar Kekerasan: Merajut Islam Indonesia Membangun Peradaban Dunia. Yogyakarta: PT LKiS Printing Cemerlang.

Abbott, J. P. (2011). Cacophony or Empowerment? Analysing the Impact of New Information Communication Technologies and New Social Media in Southeast Asia. Journal of Current Southeast Asian Affairs, 30(4), 3-31. Retrieved from \%3Cwww.CurrentSoutheastAsianAffairs.org\%3E

Abdul, G., \& Zakaria, N. (2010). Pondok Pesantren : Changes and Its Future. Journal of Islamaic and Arabic Education, 2(2), 45-52.

Abdullah, M. A. (2016). Fikih dan Kalam Sosial Era Kontemporer: Perjumpaan Ulum al-Din dan Sains Modern Menuju Fresh Ijtihad. In A. Sahal \& M. Aziz (Eds.), Islam Nusantara: dari Ushul Fiqh Hingga Paham Kebangsaan (pp. 69-97). Bandung: PT Mizan Media Pustaka.

Adichie, C. (2009). The Danger of a Single Story. Retrieved October 12, 2009, from http://www.ted.com/talks/chimamanda_adichie_the_danger_of_ a_single_story

Affan, H. (2016). Polemik di Balik Istilah -Islam Nusantara.\| Retrieved December 3, 2016, from http://www.bbc.com/indonesia/berita_indonesia/2015/06/1506 14_indonesia_isla m_nusantara

al-Amin, A. R. (2012). Membongkar Proyek Khilafah Ala Hizbut Tahrir di Indonesia. Yogyakarta: Penerbit LKiS.

Al-Ghazali, \& Faris, N. A. (1966). The Boook of Knowledge. Lahore: Sh. Muhammad Ashraf. 
JNUS: Journal of Nahdlatul Ulama Studies, Vol. 1, No. 1, Januari 2020: 34-66

Al-Qurthuby, S. (2015). Ambonese Muslim Jihadist, Islamic Identity, and the History of Christian-Muslim Rivalry in the Moluccas, Eastern Indonesia. International Journal of Asian Studies, 12(1), 1-29.

Alawi, A. (2015). Rais Aam PBNU Paparkan Landasan Islam Nusantara (Prime Leader of PBNU Explains the Ground of Islam Nusantara). Retrieved January 4, 2017, from http://www.nu.or.id/post/read/62271/rais-aam-pbnu-paparkanlandasan-islam-nusantara

Albertini, T. (2005). Crisis and Certainty of Knowledge in al-Ghazali (1058-1111) and Descartes (1596-1650). Philosophy East and West, 55(1), 1-14.

Amelia, M. (2016). Selama 2016, 300 Akun Medsos Penyebar Hoax Diblokir Polisi (During 2016, 300 Social Media Accounts which Spread Hoax were blocked by Police). Retrieved January 6, 2017, from https://news.detik.com/berita/d- 3384819/selama-2016300-akun-medsos-penyebar-hoax-diblokir-polisi

Anom, H., \& Fathoni. (2016). Keunikan NU Menurut Pengasuh Pesantren Sumber Anom (The Uniqueness of NU According to the Principal of Pesantren Sumber Anom). Retrieved

December 20, 2016, from

http://www.nu.or.id/post/read/73516/keunikan-nu-menurutpengasuh-pesantren- sumber-anom

Ansary, T. (2009). Dari Puncak Baghdad: Sejarah Dunia Versi Islam. Jakarta: Penerbit Zaman.

Az-Zarnuji. (2004). Ta'lim Mutaallim. Khartoum: Al Dar Al Soudania for Books.

Azra, A. (1992). The transmission of Islamic reformism to Indonesia: Networks of Middle Eastern and Malay-Indonesian "Ulama" in the seventeenth and eighteenth centuries. ProQuest Dissertations and Theses. Retrieved from http:/ / search.proquest.com/docview/303986118? accountid=137 71 
Azra, A. (1999). The Rise of Muslim Elite Schools: a New Pattern of -Santrinizationll In Indonesia. Al-Jami'ah, 64(XII), 63-78.

Azra, A. (2004). Political Islam in post-Soeharto Indonesia. Islamic Perspectives on the New Millennium, 133-149. https://doi.org/10.1353/prv.2005.0008

Azra, A. (2005). Islam in Southeast Asia: Tolerance and Radicalism. Miegunyah Public Lecture, 1-19.

Azra, A. (2008). Indonesian higher education: from public good to privatization. Journal of Asian Public Policy, 1(2), 139-147. https://doi.org/10.1080/17516230802094411

Azra, A. (2015). Genealogy of Indonesian Islamic Education: Roles in the Modernization of Muslim Society. Journal of Chemical Information and Modeling, 4(1), 85-114.

Azra, A. (2016). Jaringan Ulama Nusantara. In A. Sahal \& M. Aziz (Eds.), Islam Nusantara: dari Ushul Fiqh Hingga Paham Kebangsaan (pp. 169-173). Bandung: PT Mizan Media Pustaka.

Azra, A., \& Afrianty, D. (2005). Pesantren and Madrasa: Modernization of Indonesian Muslim Society. Massachusetts.

Ba'asyir, A. B. (2006). Catatan dari Penjara untuk Mengamalkan dan Menegakkan Dinul Islam. Depok: Penerbit Mushaf.

Bagir, H. (2016). Islam dan Budaya Lokal: Perspektif 'Irfan. In A. Sahal \& M. Aziz (Eds.), Islam Nusantara: dari Ushul Figh Hingga Paham Kebangsaan (pp. 175- 180). Bandung: PT Mizan Media Pustaka.

Bailin, S., \& Siegel, H. (2008). Critical Thinking. In N. Blake, P. Smeyers, R. Smith, \&

P. Standish (Eds.), The Blackwell Guide to the Philosophy of Education (pp. 181-193). Oxfo: Blackwell Publishing.

Balea, J. (2016). The Latest Stats in Web and Mobile in Indonesia (INFOGRAPHIC). Retrieved December 19, 2016, from https://www.techinasia.com/indonesia-web- mobile-statistics-weare-social

Ball, S. J. (2013). Foucault, Power, and Education. London: Routledge. 
JNUS: Journal of Nahdlatul Ulama Studies, Vol. 1, No. 1, Januari 2020: 34-66

BBC Worldwide Limited. (2016). Kaum Radikalis Lebih _Lincah\| Menggunakan Teknologi. Retrieved December 2, 2016, from

http://www.bbc.com/indonesia/berita_indonesia/2016/10/1610

12_indonesia_radi kal_teknologi

Berita Satu. (2017). Hindarkan Hoax, Kementrian Agama Kaji Fikih Bermedia Sosial (Avoiding Hoax, the Ministry of Religious Affairs Study the Islamic Jurisprudence Concerning Social Media). Retrieved January4, 2017, from http://www.beritasatu.com/hukum/407623-hindarkan-hoaxkementerian-agama- kaji-fikih-bermedia-sosial.html

Bisri, M. (2016). Sambutan (Preface). In A. Sahal \& M. Aziz (Eds.), Islam Nusantara: dari Ushul Fiqh Hingga Paham Kebangsaan. Bandung: PT Mizan Media Pustaka.

Bizawie, Z. M. (2016a). Islam Nusantara sebagai Subjek dalam Islamic Studies: Lintas Diskursus dan Metodologis (Islam Nusantara as a Subject in Islamic Studies: Inter-Discourses and Methodologies).

In A. Sahal \& M. Aziz (Eds.), Islam Nusantara: dari Ushul Fiqh Hingga Paham Kebangsaan (pp. 239-260). Bandung: PT Mizan Media Pustaka.

Bizawie, Z. M. (2016b). Masterpiece Islam Nusantara: Sanad dan Jejaring Ulama- Santri (1830-1945). Tangerang: Pustaka Compass.

Dahono, Y. (2016). Ini Alasan -Turn Back Hoaxll Dibuat (The Reasons why -Turn Back Hoaxll is Launched). Retrieved January4, 2017, from http://www.beritasatu.com/digital-life/403324-ini-alasan-turnback-hoax- dibuat.html

Dearden, L. (2017). Isis claims propaganda -more powerful than atomic bombll as groupforms strategy for survival.

Retrieved February 17, 2017, from http://www.independent.co.uk/news/world/middle-east/isispropaganda-atomic- bomb-survival-strategy-iraq-syria-islamicstate-icsr-report-amaq-rumiyah-al- a7579511.html 

(Irfan L. Sarhindi)

Departemen Agama. (2003). Undang-Undang Republik Indonesia Nomor 20 Tahun 2003 Tentang Sistem Pendidikan Nasional. UndangUndang Republik Indonesia Nomor 20 Tahun 2003 Tentang Sistem Pendidikan Nasional. https://doi.org/10.1007/s13398014-0173-7.2

Dewey, J. (1993). How We Think. Massachusetts: D.C. Heath and Company. Dhofier, Z. (1980). The Pesantren Tradition: a Study of the Role of the Kyai in the

Maintenance of the Traditional Ideology of Islam in Java. The Australian

National University. Direktorat Jenderal Kependudukan dan Pencatatan Sipil. (2013).

Undang-undang Republik Indonesia Nomor 24 Tahun 2013. Jakart:

Direktorat Jenderal Kependudukan dan Pencatatan Sipil Kementrian Dalam Negeri Republik Indonesia.

eMarketer. (2016a). In Indonesia, Facebook Remain the Most Popular Site: About $70 \%$ also say they use Instagram. Retrieved December 19, 2016, from https://www.emarketer.com/Article/IndonesiaFacebook-Remains-Most-Popular- Social-Site/1014126

eMarketer. (2016b). Indonesia Has 100 Million Internet Users, Internet Penetration at $40 \%$. Retrieved December 19, 2016, from http://www.indonesiainvestments.com/news/todays-headlines/indonesia-has-100million-internet- users-internet-penetration-at-40/item6827?

Evers, H.-D. (2016). Nusantara: History of a Concept. Journal of the Malaysian Branch of the Royal Asiatic Society, 89(1), 3-14. https://doi.org/10.1353/ras.2016.0004

Fachrudin, A. A. (2016). Islam Nusantara dan Hal-hal yang Belum Selesai. In A. Sahal \& M. Aziz (Eds.), Islam Nusantara: dari Ushul Fiqh Hingga Paham Kebangsaan (pp. 261-272). Bandung: PT Mizan Media Pustaka.

Fathoni. (2016). Sikapi Maraknya Hoax, Dai Muda Tingkatkan Literasi Media (Responding the Spreading of Hoax, Young Islamic Preachers Encourage Media Literacy). Retrieved January 4, 2017, 
JNUS: Journal of Nahdlatul Ulama Studies, Vol. 1, No. 1, Januari 2020: 34-66

from http://www.nu.or.id/post/read/74373/sikapi-maraknyahoax-dai-muda-tingkatkan- kemampuan-literasi-media

Fatoni, M. S. (2016). NU dan Islam Nusantara. In A. Sahal \& M. Aziz (Eds.), Islam Nusantara: dari Ushul Fiqh Hingga Paham Kebangsaan (pp. 229-238). Bandung: PT Mizan Media Pustaka.

Fealy, G. (2004). Islamic Radicalism in Indonesia: The Faltering Revival? Southeast Asian Affairs, 104-121.

Fealy, G. (2016). Bigger than Ahok: explaining the 2 December mass rally. Retrieved December 10, 2016, from http://indonesiaatmelbourne.unimelb.edu.au/bigger- than-ahokexplaining-jakartas-2-december-mass-rally/

Fox, J. J. (2004). Currents in Contemporary Islam in Indonesia. Harvard Asia Vision 21, 1-24.

Geertz, C. (1960). The Javanese Kijaji: The Changing Role of a Cultural Broker. Society for Comparative Studies in Society and History, 2(2), 228-249. https://doi.org/10.1017/S0010417500000670

Ghazali, A. M. (2016). Metodologi Islam Nusantara. In A. Sahal \& M. Aziz (Eds.), Islam Nusantara: dari Ushul Fiqh Hingga Paham Kebangsaan (pp. 106-116). Bandung: PT Mizan Media Pustaka.

Gillespie, P. (2007). Current Issues in Indonesian Islam: Analysing the 2005 Council of Indonesian Ulama Fatwa No. 7 Opposing Pluralism, Liberalism and Secularism. Journal of Islamic Studies, 18(2), 202-240.

https://doi.org/10.1093/jis/etm001

Gore, J. M. (1998). Disciplining the Bodies: On the Continuity of Power Relations in Pedagogy. In T. S. Popkewitz \& M. Brennan (Eds.), Foucault's Challenge: Discourse, Knowledge, and Power in Education (pp. 231-251). London: Teachers College Press.

Gregerson, J. (2012). Truth, Lies, and Rumors in the Media: Consider the Source. Journal of the Academy of Nutrition and Dietetics, 112(5), 602. https://doi.org/10.1016/j.jand.2012.03.007

Gunawan, A. (2016). Indonesia Second Least Literate of 61 Nations. Retrieved December 19， 2016， from 
http://www.thejakartapost.com/news/2016/03/12/indonesiasecond-least-literate- 61-nations.html

Halstead, M. (2004). An Islamic concept of education. Comparative Education, 40(4), $517-529$. https://doi.org/10.1080/0305006042000284510

Hamayotsu, K. (2013). The Limits of Civil Society in Democratic Indonesia: Media Freedom and Religious Intolerance. Journal of $\begin{array}{llll}\text { Contemporary } & \text { Asia, } & 43(4), & 658-\end{array}$ https://doi.org/10.1080/00472336.2013.780471

Hassan, R. (2007). On Being Religious: Patterns of Religious Commitment in Muslim Societies. The Muslim World, 97, 437-478.

Hefner, R. W. (2012). ReviewThe Makings of Indonesian Islam: Orientalism and the Narration of a Sufi Past. Asian Affairs, 43(February 2015), 333-334.

Hendroyono, T. (2004). Dunia Islam di Internet. Solo: Penerbit Katta.

Howell, J. D. (2001). Sufism and the Indonesian Islamic Revival. The Journal of Asian Studies, 60(3), 701-729. https://doi.org/10.2307/2700107

Hytten, K. (2004). Democracy and John Dewey. In J. L. Kincheloe \& D. Weil (Eds.), Critical Thinking and Learning: an encyclopedia for parents and teachers. Wstport: Greenwood Press.

Jackson, E., \& Bahrissalim. (2007). Crafting a New Democracy Civic education in Indonesian Islamic universities. Asia Pacific Journal of Education, 27(1), 41-54.

Jati, W. R. (2013). Radicalism in the Perspective of Islamic-Populism: Trajectory of Political Islam in Indonesia. Journal of Indonesian Islam, 7(2).

Kincheloe, J. L. (2008). Knowledge and Critical Pedagogy. Dordrecht: Springer. Kraince, R. G. (2007). Islamic higher education and social cohesion in Indonesia.

Prospect, 37, 345-356. https://doi.org/10.1007/s11125-008-9038-1 
JNUS: Journal of Nahdlatul Ulama Studies, Vol. 1, No. 1, Januari 2020: 34-66

Kurfiss, J. G. (1988). Critical Thinking: Theory, Research, Practice, and Possibilities. ASHE-ERIC Higher Education Report, 2.

Kurniasih, I., \& Sani, B. (2014). Implementasi Kurikulum 2013 Konsep dan Penerapan. Jakarta.

Lim, M. (2005). Islamic Radicalism and Anti-Americanism in Indonesia: The Role of the Internet. Policy Studies, 18, 1-49.

Lim, M. (2013a). Many Clicks but Little Sticks: Social Media Activism in Indonesia. Journal of Contemporary Asia, 43(4), 636-657. https://doi.org/10.1080/00472336.2013.769386

Lim, M. (2013b). The Internet and Everyday Life in Indonesia: A New Moral Panic? Bijdragen Tot de Taal-, Land- En Volkenkunde / Journal of the Humanities and Social Sciences of Southeast Asia, 169(1), 133-147. https://doi.org/10.1163/22134379-12340008

Loras, S. (2016). Social media in Indonesia: big number with plenty of room to grow. Retrieved December 19, 2016, from https://www.clickz.com/social-media-in- indonesia-big-numberswith-plenty-of-room-to-grow/94062/

Lukens-Bull, R. A. (2001). Two Sides of the Same Coin: Modernity and Tradition in Islamic Education in Indonesia. Anthropology \& Education Quarterly, 32(3), 350-372.

Lukens-Bull, R. A. (2013). Islamic Higher Education in Indonesia: Continuity and Conflict. New York: Palgrave Macmillan.

Madjid, N. (2003). The True Face of Islam: Essays on Islam and Modernity in Indonesia. Ciputat: Voice Center Indonesia.

Manshur, I. (2014). Jumlah Warga NU 83 Juta Jiwa? (The Amount of NU‘s Member Reaches 83 million?). Retrieved January 4, 2017, from http://www.muslimedianews.com/2014/05/jumlah-warganu-83-juta-jiwa-di.html

Marshall, D. (2012). Max Weber - Types of Authority. Retrieved October 18, 2016, from https://www.youtube.com/watch?v=rZTtQRWTZE

Mas'udi, M. F. (2016). Syarah Konstitusi: UUD 1945 dalam Perspektif Islam. In A. Sahal \& M. Aziz (Eds.), Islam Nusantara: dari Ushul 
Fiqh Hingga Paham Kebangsaan (pp. 287-320). Bandung: PT Mizan Media Pustaka.

Memory of Majapahit. (2007). Bhineka Tunggal Ika. Retrieved from http://www.eastjava.com/books/majapahit/html/bhinneka.html

Milla, M. N., Faturochman, \& Ancok, D. (2013). The impact of leaderfollower interactions on the radicalization of terrorists: A case study of the Bali bombers. Asian Journal of Social Psychology, 16(2), 92-100. https://doi.org/10.1111/ajsp.12007

Miller, J. W., \& McKenna, M. C. (2016). Rank Breakdown. Retrieved December 19, 2016, from http://www.ccsu.edu/wmln/rank.html Moon, J. (2007). Critical Thinking: an Exploration of Theory and Practice. London: Routledge.

Muhadjir, A. (2016). Islam Nusantara untuk Peradaban Indonesia dan Dunia. In A. Sahal \& M. Aziz (Eds.), Islam Nusantara: dari Ushul Fiqh Hingga Paham Kebangsaan. Bandung: PT Mizan Media Pustaka.

Muhammad, H. (2016). Hukum Islam yang Tetap dan yang Berubah. In A. Sahal \&

M. Aziz (Eds.), Islam Nusantara: dari Ushul Fiqh Hingga Paham Kebangsaan (pp. 98-105). Bandung: PT Mizan Media Pustaka.

Muhammad, N. (2012). Karakteristik Jaringan Ulama Nusantara Menurut Pemikiran Azyumardi Azra. Jurnal Substantia, V Ol . 14 , No. 1 , April 201 2, 14(128), 73-87. Retrieved from http://substantiajurnal.org/index.php/subs/article/viewFile/80/ 78

Muizzuddin, M. (2012). Etika Belajar dalam Kitab Ta'lim Muta'alim. AlIttijah, 4(4), 1- 18.

Mujiburrahman. (2007). Indonesian Muslims in the Public Sphere: a Review of Several Studies. Journal of Indonesian Islam, 1(2), 356378.

Musa, A. M. (2014). Membumikan Islam Nusantara: Respons Islam terhadap Isu-Isu Faktual. Jakarta: PT Serambi Ilmu Semesta. 
JNUS: Journal of Nahdlatul Ulama Studies, Vol. 1, No. 1, Januari 2020: 34-66

Muzakki, A. (2014). The Roots, Strategies, and Popular Perception of Islamic Radicalism in Indonesia. Journal of Indonesian Islam, 8(1), 1-22. https://doi.org/10.15642/JIIS.2014.8.1.1-22

Najmudin, A., \& Alawi, A. (2016). Kader Muda NU Solo Siap Deklarasikan Masyarakat Antihoax (Young Cadres of NU in Solo are Ready to Declare the Anti-hoax Society). Retrieved January 4, 2017, from http://www.nu.or.id/post/read/74332/kader-muda-nu-solo-siapdeklarasikan- masyarakat-anti-hoax

Nasuhi, H., \& Darmanji, A. (2009). The Syarif Hidayatullah State Islamic University and the development of society. Studia Islamika: Indonesian Journal for Islamic Studies, $\quad$ 16(2), 291-302.

Retrieved from http:// search.proquest.com/docview/1021122299?accountid=98 51\%5Cnhttp://tf5 lu9ym5n.search.serialssolutions.com/?ctx_ver=Z39.882004\&ctx_enc=info:ofi/enc:UTF8\&rfr_id=info:sid/ProQ\%3Aibssshell\&rft_val_fmt=info:ofi/fmt: kev:mtx:journal\&rft. genre $=$ article\&rft.jti

Ngelow, Z. J. (n.d.). Interfaith Cooperation against Radicalism and Violence in Indonesia: A Christian perspective 1.

Noor, H. (2013). Making Muslims, Making News: Mediating Political Identities in the War on Terror. Institute of Education, University of London.

Nor, M. R. M., \& Malim, M. (2014). Revisiting Islamic education: the case of Indonesia. Journal for Multicultural Education, 8(4), 261-276. https://doi.org/10.1108/JME-05-2014-0019

NU Online. (2015). Tentang NU. Retrieved December 15, 2016, from http://www.nu.or.id/about/

Ocean of Wisdom. (2015). al-Ghazali -- Book of Knowledge -- Readings from Ihya Ulum al-Din. Retrieved October 7, 2016, from https://www.youtube.com/watch?v=h_uRFN1gpb0 
Osman, M. N. M. (2010). Reviving the Caliphate in the Nusantara: Hizbut Tahrir Indonesia's Mobilization Strategy and Its Impact in Indonesia. Terrorism and Political Violence, 22(4), 601-622. https://doi.org/10.1080/09546553.2010.496317

Osman, S. (2012). Is Atheism Illegal in Indonesia? Retrieved October 26, 2016, from http://jakartaglobe.beritasatu.com/archive/isatheism-illegal-in-indonesia/

Parker, L. (2016). Religious environmental education? The new school curriculum in Indonesia. Environmental Education

Research, 1-24. https://doi.org/10.1080/13504622.2016.1150425

Penebar Cahaya Islam. (2016). Kontroversi Islam Nusantara Menurut Berbagai Tokoh Islam. Retrieved December 3, 2016, from https://islamislami.com/2016/06/26/kontroversiislam-nusantara-menurut- berbagai-tokoh-islam/

PP-Muhammadiyah. (2000). Pedoman kehidupan islami warga muhammadiyah, 25. Pringle, R. (2016). Understanding Islam in Indonesia: Politics and Diversity. Singapore: Didier Millet PTE Ltd.

Quran. (n.d.). The Noble Quran. Retrieved October 12, 2016, from https://quran.com/

Rahman, F. (1980). Islam: Legacy and Contemporary Challenge. Islamic Studies, 19(4), 235-246.

Raihani. (2014). Creating Multicultural Citizens: a Portrayal of contemporary Indonesian education. London: Routledge.

Raindrop Academy. (2014). Elevate to the Angelic State by Knowing Yourself. Retrieved October 7, 2016, from https://www.youtube.com/watch?v=PWvObNrkFAQ\&list=PLV J4u_814FOFfi50Q KEKrWpbuz7HAbLov

Raindrop Academy. (2015a). 8 Things to do on your spiritual journey. Retrieved October 7, 2016, from https://www.youtube.com/watch?v=RUhI72igSEg 
JNUS: Journal of Nahdlatul Ulama Studies, Vol. 1, No. 1, Januari 2020: 34-66

Raindrop Academy. (2015b). How to Access Divine Knowledge. Retrieved October 7, 2016, from https://www.youtube.com/watch?v=glZId6JU6k4\&list=PLVJ4u _814FOFfi50QKE KrWpbuz7HAbLov\&index=4

Raindrop Academy. (2015c). Speak Truth to Purify Your Heart. Retrieved October 7, 2016, from https://www.youtube.com/watch?v=YJZTyF6bOMU

Raindrop Academy. (2016). Belief is the Seed of Spiritual Happiness. Retrieved October 7, 2016, from https://www.youtube.com/watch?v=TkT_CuZjkSA

Ramadan, T. (2008). Radical Reform: Islamic Ethics and Liberation. Ethics and Universals, 1-26.

Ramage, D. E. (1995). Politics in Indonesia: democracy, Islam, and the ideology of tolerance. Politics in Asia. https://doi.org/10.2307/2658481

Ritchey, J. A., \& Muchtar, N. (2000). Indonesian Pesantren and Community Social Change: Moderate Islam 's Use of Media and Technology for Nonformal , Community-Based Education, $420-425$.

Ropi, I. (2016). Islamic Religious Texts Must be Read in Context to Understand Blasphemy. Retrieved December 3, 2016, from http://www.thejakartapost.com/academia/2016/12/02/islamicreligious-texts- must-be-read-in-context-to-understandblasphemy.html

Rosidin, D. N. (2012). Pesantren and Modernity in Indonesia: Ma'had Aly of Kuningan. HUNAFA: Jurnal Studia Islamika. Retrieved from http://jurnalhunafa.org/index.php/hunafa/article/view/74

Saeed, A. (1999). Towards Religious Tolerance through Reform in Islamic Education: The case of the State Institute of Islamic Studies of Indonesia. Indonesian and the Malay World, 27(79), 177-191. https://doi.org/10.1080/13639819908729941 
Sahal, A. (2016). Prolog. In A. Sahal \& M. Aziz (Eds.), Islam Nusantara: dari Ushul Fiqh Hingga Paham Kebangsaan (pp. 15-30). Bandung: PT Mizan Media Pustaka.

Sakai, M., \& Fauzia, A. (2014). Islamic orientations in contemporary Indonesia: Islamism on the rise? Asian Ethnicity, 15(1), 41-61. https://doi.org/10.1080/14631369.2013.784513

Siroj, S. A. (2016). Rekonstruksi Aswaja Sebagai Etika Sosial: Akar-akar Teologi Moderasi Nahdlatul Ulama. In A. Sahal \& M. Aziz (Eds.), Islam Nusantara: dari Ushul Fiqh Hingga Paham Kebangsaan (pp. 137-168). Bandung: PT Mizan Media Pustaka.

Sirozi, M. (2005). The Intellectual Roots of Islamic Radicalism in Indonesia. The Muslim World, 95, 81-120.

Smith, B. J., \& Hamdi, S. (2013). Between Sufi and Salafi subjects; female leadership, spiritual power and gender matters in Lombok. In B. J. Smith \& M. Woodward (Eds.), Gender and Power In Indonesian Islam: Leaders, Feminists, Sufis and Pesantren Selves (pp. 25-48). New York: Routledge. https://doi.org/10.4324/9780203797518

Smith, P. (2013). Weber's Concepts of Charisma and Its Routinization. Retrieved October 18, 2016, from https://www.youtube.com/watch?v=-C7D2WYUs3Y

Sonn, T. (1991). Fazlur Rahman's Islamic Methodology. The Muslim World, 81(3-4), 212-230. https://doi.org/10.1111/j.14781913.1960.tb01060.x

Spencer, M. E. (1973). What is Charisma? The British Journal of Sociology, 24(3), 341-354.

Springer, D. R., Regens, J. L., \& Edger, D. N. (2009). Islamic Radicalism and Global Jihad. Washington DC: Georgetown University Press.

Staquf, Y. C. (2016). Islam Merangkul Nusantara. In A. Sahal \& M. Aziz (Eds.), Islam Nusantara: dari Ushul Fiqh Hingga Paham Kebangsaan (pp. 191-201). Bandung: PT Mizan Media Pustaka.

Sunnah. (n.d.). The Hadith of the Prophet Muhammad at Your Fingertips. Retrieved October 12, 2016, from http:/ / sunnah.com/ 
JNUS: Journal of Nahdlatul Ulama Studies, Vol. 1, No. 1, Januari 2020: 34-66

Syamsudin, D. (2016). NKRI: Negara Perjanjian dan Kesaksian. In A. Sahal \& M. Aziz (Eds.), Islam Nusantara: dari Ushul Fiqh Hingga Paham Kebangsaan (pp. 278-286). Bandung: PT Mizan Media Pustaka.

Tan, C. (2011). Islamic Education and Indoctrination: The Case in Indonesia. London: Routledge.

Tan, C. (2014). Educative tradition and Islamic schools in Indonesia Educative Tradition and Islamic Schools in Indonesia. Journal of Arabic and Islamic Studies, 14(14), 47-62.

Tarsono, W. (2015). Tokoh Penganut Kepercayaan: -Sudah Matipun Kami Masih Didiskriminasi.\| Retrieved December 5, 2016, from http://www.madinaonline.id/sosok/wawancara/tokohpenghayat-kepercayaan- sudah-mati-pun-kami-masihdidiskriminasi/

Temby, Q. (2010). Imagining an Islamic State in Indonesia: From Darul Islam to Jemaah Islamiyah. Indonesia, 89, 1-36.

The Constitutional Court of the Republic of Indonesia. (2015). The 1945 Constitution of the Republic of Indonesia: Law of the Republic of Indonesia Concerning the Constitutional Court. Jakarta: The Office of the Registrar and the Secretariat General of the Constitutional Court of the Republic of Indonesia.

Tim Karya Ilmiah Purna Siswa. (2014). Jejak Sufi: Membangun Moral Berbasis Spiritual. Kediri: Lirboyo Press.

Tim Penulis JNM. (2015). Gerakan Kultural Islam Nusantara. Yogyakarta: Jamaah Nahdliyin Mataram and Panitia Muktamar NU ke-33.

USAID. (2007). Analysis of the Current Situation of Islamic Formal Junior Secondary Education in Indonesia (Vol. 3).

van Bruinessen, M. (1990). Kitab Kuning; Books in Arabic Script used in the Pesantren mileu; Comment on a new collection in the KITLV Library. Bijdragen Tot de Taal-, Land- En Volkenkunde, 146(2/3), 226-269. 
van Bruinessen, M. (2013). Introduction: Contemporary Developments in Indonesian Islam and the -Conservative Turnll of the Early Twenty-First Century. In M. van Bruinessen (Ed.), Contemporary Development in Indonesian Islam, Explaining the "Conservative Turn” (pp. 1-19). Singapore: ISEAS-Yusof Ishak Institute.

Van Bruinessen, M. (1994). Pesantren and Kitab Kuning: Maintenance and Continuation of a Tradition of Religious Learning. In W. Marschall (Ed.), Text from the Islands. Oral and Written traditions of Indonesia and the Malay world (pp. 121-145). Berne: University of Berne.

Van Bruinessen, M. (2013). Overview of Muslim Organizations, Associations and

Movements in Indonesia. In M. van Bruinessen (Ed.), Contemporary Development in Indonesian Islam, Explaining the "Conservative Turn” (pp. 21- 59). Singapore: ISEAS-Yusof Ishak Institute.

Varisco, D. M. (2010). Muslims and the media in the blogosphere. Contemporary Islam, 4(1), 157-177. https://doi.org/10.1007/s11562-009-0106-y

Waghid, Y. (2014). Islamic Education and Cosmopolitanism: A Philosophical Interlude. Studies in Philosophy and Education, 33(3), 329-342. https://doi.org/10.1007/s11217-013-9390-3

Wahid, A. (2006). Islamku Islam Anda Islam Kita: Agama Masyarakat Negara Demokrasi. Jakarta: The Wahid Institute.

Wahid, A. (2016a). Paham Kebangsaan NU. In A. Sahal \& M. Aziz (Eds.), Islam Nusantara: dari Ushul Fiqh Hingga Paham Kebangsaan (pp. 274-277). Bandung: PT Mizan Media Pustaka.

Wahid, A. (2016b). Pribumisasi Islam. In A. Sahal \& M. Aziz (Eds.), Islam Nusantara: dari Ushul Fiqh Hingga Paham Kebangsaan (pp. 3348). Bandung: PT Mizan Media Pustaka.

Wahid, A., Ghazali, A. M., Muhadjir, A., Abdullah, A., Fachrudin, A. A., Fatoni, M. S., Bizawie, Z. M. (2016). Islam Nusantara: dari Ushul Fiqh Hingga Paham Kebangsaan. (A. Sahal \& A. Munawir, Eds.). Bandung: PT Mizan Media Pustaka. 
JNUS: Journal of Nahdlatul Ulama Studies, Vol. 1, No. 1, Januari 2020: 34-66

Weil, D. (2004). Believing and Knowing. In J. L. Kincheloe \& D. Weil (Eds.), Critical Thinking and Learning: an encyclopedia for parents and teachers. Wstport: Greenwood Press.

Wildan, M. (2013). Mapping Radical Islam: a Study of the Proliferation of Radical Islam in Solo, Central Java. In M. van Bruinessen (Ed.), Contemporary Development in Indonesian Islam: Explaining the Conservative Turn (pp. 190- 223). Singapore: ISEAS-Yusof Ishak Institute.

Woodward, M., Rohmaniyah, I., Amin, A., \& Coleman, D. (2010). Muslim Education, Celebrating Islam and Having Fun As CounterRadicalization Strategies in Indonesia. Perspective on Terrorism, 4(4), 28-50.

Woodward, M., Yahya, M., Rohmaniyah, I., Coleman, D. M., Lundry, C., \& Amin, A. (2014). The Islamic Defenders Front: Demonization, Violence and the State in Indonesia. Contemporary Islam, 8(2), 153-171. https://doi.org/10.1007/s11562-013-0288-1

Zaqzuq, M. H. (2004). Reposisi Islam di Era Globalisasi. Yogyakarta: Pustaka Pesantren.

Zaqzuq, M. H. (2008). Islam Dihujat Islam Menjawab: Tanggapan atas Tuduhan dan Kesalahpahaman. Jakarta: Lentera Hati.

Zuhdi, M. (2006). Modernization of Indonesian Islamic schools‘ curricula, 1945-2003. International Journal of Inclusive Education, 10(4-5), 415-427. https://doi.org/10.1080/13603110500430765

Zulfa, \& Alhafiz, K. (2016). Aktivis Cyber Aswaja Satukan Visi Perangi Hoax di Medsos (The Activitists of Cyber Aswaja Unify their Visions to Curb Hoax in Social Media). Retrieved January 4, 2017, from http://www.nu.or.id/post/read/74283/aktivis-cyber-aswajasatukan-visi-perangi- hoax-di-medsos 